\title{
Recent advances in magnetic resonance imaging of prostate cancer Nathan Lawrentschuk ${ }^{1}$ and Uri Lindner ${ }^{2 *}$
}

\author{
Addresses: ${ }^{1}$ University of Melbourne, Department of Surgery, Urology Unit and Ludwig Institute for Cancer Research, Austin Hospital, Heidelberg, \\ VIC 3084, Australia; ${ }^{2}$ Department of Urology, Tel Hashomer Hospital (affiliated with Tel Aviv University), 52621, Israel \\ * Corresponding author: Uri Lindner (lindneruri@gmail.com) \\ FI000 Medicine Reports 2010, 2:86 (doi:10.3410/M2-86) \\ This is an open-access article distributed under the terms of the Creative Commons Attribution-Non Commercial License \\ (http://creativecommons.org/licenses/by-nc/3.0/legalcode), which permits unrestricted use, distribution, and reproduction in any medium, \\ provided the original work is properly cited. You may not use this work for commercial purposes. \\ The electronic version of this article is the complete one and can be found at: http://f1000.com/reports/m/2/86
}

\begin{abstract}
This concise review attempts to highlight the recent advances in magnetic resonance imaging (MRI) in relation to all the different aspects of prostate cancer (PCa), and outlines future implications of MRI in the diagnosis, treatment, and surveillance of PCa.
\end{abstract}

\section{Introduction and context}

Prostate cancer $(\mathrm{PCa})$ is the most common malignancy in men - around 200,000 new cases were diagnosed in the US in 2009 - and is responsible for the highest rate of malignancy related mortality after lung cancer [1]. Currently, trans-rectal ultrasound-guided biopsy (TRUS-Bx) is the 'gold standard' for diagnosis of PCa. However, TRUS-Bx can lead to serious infections and urosepsis, reported in at least $2-4 \%$ of patients [2].

Upon diagnosis of $\mathrm{PCa}$, management decisions pose a dilemma for both the patient and physician. Despite the Scandinavian Prostate Cancer Group Study $[3,4]$ and the European Randomized Study of Screening for Prostate Cancer [5] providing evidence of a reduction in diseasespecific mortality in screened and treated PCa populations, it is estimated that between 25 and $84 \%$ of PCa patients currently being treated will not succumb to their disease should they be left untreated, in other words, they have a clinically insignificant form of the disease $[4,6-10]$.

Therefore, a sensitive and specific enough imaging modality is needed to help discern between patients with insignificant disease and the patients in need of treatment, and it might also alleviate the need for biopsies to be taken for accurate diagnosis, or at least significantly lower the number of biopsy cores needed.

One such modality is magnetic resonance imaging (MRI), which has been used to evaluate prostate anatomy and prostate diseases since 1982 [11]. MRI is able to provide detailed anatomical images, particularly of soft tissues, at high spatial resolution, and when combined with the ability to provide functional measurements has lead investigators to extensively explore the role of MRI in diagnosis and staging of PCa. Different sequences (the manner in which the magnet creates pulses and interfaces with the data collected) have been manipulated and even combined to give the greatest information (e.g., contrastenhanced imaging combined with magnetic resonance spectroscopy).

\section{Recent advances \\ Tumor localization}

MRI PCa localization began with the usage of T2-weighted (T2W) imaging to visualize the anatomy and the architecture of the prostate gland. PCa may be seen as an area with low signal intensity; however, several benign conditions, such as prostatitis, intra-prostatic hemorrhage, and scarring, have a similar appearance, therefore this method has a relatively low specificity of $54-82 \%$ and a widely varied sensitivity of 46-96\% [12-14]. However, in addition to anatomic information, MRI can elucidate physiological properties of tissue through different imaging techniques such as diffusion-weighted MRI (DW-MRI), which measures the diffusion of water molecules in tissue. Due to its increased cellular density, PCa shows restricted diffusion. Dynamic contrastenhanced MRI (DCE-MRI) is another technique that assesses the microvascular properties of tissue. As PCa has 
an abundant microvasculature, tumors usually show an early signal enhancement and washout of signal intensity. Finally, magnetic resonance spectroscopic imaging (MRSI) can be used to measure metabolite levels in the tissue, particularly choline, citrate, creatine, and various polyamines. PCa usually exhibits an increased concentration of choline, a reduction of citrate, and lower levels of polyamines. Creatine is usually unaffected.

Each imaging technique has been tried separately and been shown to improve PCa localization and detection, but much more interesting is the recent usage of the different modalities in combination, such as multiparametric MRI scanning, which has an improved specificity and sensitivity. Recently, Kitajima et al. [15] reported a specificity of $95 \%$ and sensitivity of $80 \%$ using 3 telsa (3T) MRI and multiparametric scanning. These results have been repeated in many similarly designed trials $[16,17]$.

\section{Tumor volume}

In addition to resolving the tumor location, assessing the tumor volume might help with decisions related to the management of the tumor. There is a large variability and generally a poor correlation between MRI-measured tumor volumes and pathologic-examination tumor volume using conventional T2W imaging $[18,19]$. However, combining different imaging techniques has been shown to significantly increase the accuracy of MRIcalculated tumor volume $[19,20]$. It is now possible to delineate the tumor with accuracy using MRI, providing a 'safety margin' of $5 \mathrm{~mm}$ is maintained [21]. (The safety margin is the rim outside the delineated tumor volume needed to be treated in order to avoid leaving viable tumor cells.) Delineating tumors allows for targeted therapies to be implemented.

\section{Tumor aggressiveness}

Tumor biology as currently graded by the Gleason score is one of the key prognostic factors of PCa patients $[22,23]$. In order to achieve accurate grading one must attain a tissue sample by biopsy. Yet even today, despite more cores being taken per biopsy session, there are still often discrepancies between biopsy samples and final histopathology reports [24].

MRSI is a noninvasive diagnostic tool to assess cancer metabolism and elucidate its biological propensities [25-27]. There is enough evidence to suggest that by using MRSI, risk criteria can be assigned for PCa patients even more accurately than with the Gleason grade determined using TRUS-Bx $[28,29]$. However, larger studies in multiple centres are required to confirm this observation.

\section{MRI guidance for prostate biopsies}

TRUS-Bx, which is currently the 'gold standard' for PCa detection, relies on random sampling of the prostate [30], hence the recent trend for a greater number of core biopsies being taken per patient in order to increase the detection of PCa [31-33]. This can be partly avoided, however, by using lesions that appear suspicious on MRI to direct TRUS-Bx. This has been shown to greatly improve PCa detection in patients with prior negative biopsy and suspicion of harbouring malignancy [34-37].

MRI-guided biopsies have also been performed [38-42] but only limited data is available thus far regarding their efficacy and no trial has compared MRI-guided prostate biopsies with TRUS-Bx.

\section{MRI-guided prostatic interventions}

MRI has been used to guide and monitor ablations in a variety of tumors [43-47] including in PCa [48]. In fact, MRI has also been utilized to accurately place high-doserate brachytherapy rods $[49,50]$.

MRI has the unique capability to measure the temperature distribution in the prostate gland continuously during thermal ablative treatment to enable delivery of adaptive therapy. This continuous monitoring can be used to compensate for changes in blood flow, prostate size, and minor prostate movement. In addition, quantitative knowledge of the amount of heating in surrounding tissues can be used to protect these regions from thermal damage.

Chen et al. [51] performed MRI-guided percutaneous interstitial microwave thermoablation of locally recurrent PCa. MRI-derived temperatures were linearly related to the tissue temperatures, measured with an MRIcompatible thermosensor, therefore they concluded that MRI can be used to guide thermoablation. Chopra et al. showed that using MRI thermometry while applying trans-urethral MRI-guided high intensity-focused ultrasound (HIFU) allowed for stable temperature measurements, which were achieved with a standard deviation of approximately $\pm 1^{\circ} \mathrm{C}[52]$.

\section{Assessment of treatment effects and recurrent disease}

After different treatments have been conducted that aim to destroy the tumor and leave the prostate behind (such as external beam radiation and focal therapy), it is important to accurately assess the ablation size and validate that it encompassed the desired pre-treatment ablation area, as well as to diagnose disease recurrence.

In order to evaluate the ability of MRI to accurately define ablation volume, Djavan et al. [53] utilized radiofrequency 
energy to create intraprostatic lesions and demonstrated good correlation between MRI-calculated volume and volume calculated using hematoxylin and eosin (H\&E) stains. Larson et al. [54] found a strong correlation ( $r=$ 0.92 ) between MRI volumetric assessment of damage and $\mathrm{H} \& \mathrm{E}$ assessment of damage when using different minimally invasive treatment modalities to create intraprostatic lesions.

Far more recent studies have shown that MRI is a promising imaging biomarker for therapeutic response of PCa to radiotherapy [55] and allows detection of PCa recurrence after external radiation therapy treatment $[56,57]$ or HIFU treatment [58].

Local persistence or progression after radical prostatectomy is a major reason why prostate-specific antigen (PSA) levels may still be elevated after treatment $[59,60]$. TRUS of the prostatic fossa in association with TRUS-Bx is considered more sensitive than a digital rectal examination for detecting local recurrence, especially if PSA levels are low [61]. However, TRUS is unlikely to detect tumor mass at low PSA levels $(<1 \mathrm{ng} / \mathrm{ml})$ and the role of a biopsy remains unclear, specifically, whether there is really a need to take a biopsy in the event of PSA failure.

Accurate identification of local recurrence with pelvic imaging might improve the effectiveness of tumor eradication with radiotherapy, as MRI has been shown to identify residual disease even when low PSA levels have been detected $[62,63]$. It seems that DCE imaging further improves the ability to detect local recurrence in patients at high risk of post-prostatectomy failure $[64,65]$.

\section{Active surveillance and MRI}

To combat potential overtreatment of clinically insignificant cancer, active surveillance has emerged as an alternative management strategy [66]. Patients who are suspected of having insignificant PCa based on physical examination, PSA levels, and TRUS-Bx results (comprising Gleason score, the number of positive cores, and the percentage of core infiltrated by tumour) are actively monitored. Should the suspicion arise that the disease is progressing or 'active' (as opposed to insignificant disease) based on PSA (rise or kinetics), rectal examination, and repeat biopsies, the patient would undergo curative whole gland treatment. This scheme offers curative treatment to patients we believe warrant it while avoiding inflicting unwarranted side effects on patients who do not need treatment (due to an insignificant disease) [66].

van As et al. [67] analysed the apparent diffusion coefficient (ADC) generated from DW-MRI with respect to repeat biopsy findings and time to radical treatment in
86 patients in a prospective study of active surveillance. They demonstrated that a low ADC is associated with adverse histology on repeat biopsy and shorter time to deferred radical treatment. Tumor ADC was highly and significantly correlated with maximum core involvement, percentage of positive cores, and the ratio of free/ total PSA. Tumor ADC was also significantly correlated with initial PSA level, but not with PSA velocity.

In a recent retrospective study, Fradet et al. [68] demonstrated that patients with lesion findings suggestive of PCa on MRI were at a higher risk for Gleason score upgrading on a subsequent prostate biopsy.

\section{Implications for clinical practice}

MRI is fast becoming a multipurpose imaging modality and might soon change the way we think and treat PCa. It is quite plausible that, in the near future, patients who are suspected of harbouring PCa due to elevated serum markers (PSA, PCA3 [prostate cancer antigen 3], or others) will undergo an MRI scan and, according to the results, will either be told all is well or go on an active surveillance protocol, undergo an MRI-guided focal ablation, or go through radical treatment. It stands to reason that the follow-up regimen will consist of biomarker detection and MRI scans; however, currently, the role of MRI is still limited and not well defined by clinical guidelines.

The authors use this imaging tool mostly in patients who have had a previous negative biopsy and are suspected of harbouring $\mathrm{PCa}$, and in prospective studies of patients who are candidates for an active surveillance protocol.

\section{Abbreviations}

ADC, apparent diffusion coefficient; DCE-MRI, dynamic contrast-enhanced MRI; DW-MRI, diffusion-weighted MRI; H\&E, hematoxylin and eosin; HIFU, high intensity-focused ultrasound; MRI, magnetic resonance imaging; MRSI, magnetic resonance spectroscopic imaging; $\mathrm{PCa}$, prostate cancer; PSA, prostate-specific antigen; T2W, T2-weighted; TRUS-Bx, trans-rectal ultrasoundguided biopsy.

\section{Competing interests}

The authors declare that they have no competing interests.

\section{References}

I. Jemal A, Siegel R, Ward E, Hao Y, Xu J, Thun MJ: Cancer statistics, 2009. CA Cancer J Clin 2009, 59:225-49.

2. Tiong HY, Liew LC, Samuel M, Consigliere D, Esuvaranathan K: A meta-analysis of local anesthesia for transrectal ultrasoundguided biopsy of the prostate. Prostate Cancer Prostatic Dis 2007, I0:127-36. 
3. Bill-Axelson A, Holmberg L, Filén F, Ruutu M, Garmo H, Busch C, Nordling $S$, Häggman $M$, Andersson SO, Bratell $S$, Spångberg $A$, Palmgren J, Adami HO, Johansson JE; Scandinavian Prostate Cancer Group Study Number 4: Radical prostatectomy versus watchful waiting in localized prostate cancer: the Scandinavian prostate cancer group-4 randomized trial. J Natl Cancer Inst 2008, I00: I |44-54

4. Johansson JE, Andrén O, Andersson SO, Dickman PW, Holmberg L, Magnuson A, Adami HO: Natural history of early, localized prostate cancer. JAMA 2004, 291:2713-9.

5. Schröder FH, Hugosson J, Roobol MJ, Tammela TL, Ciatto S, Nelen V, Kwiatkowski M, Lujan M, Lilja H, Zappa M, Denis LJ, Recker F, Berenguer A, Määttänen L, Bangma CH, Aus G, Villers A, Rebillard X, van der Kwast T, Blijenberg BG, Moss SM, de Koning HJ, Auvinen A; ERSPC Investigators: Screening and prostate-cancer mortality in a randomized European study. N Engl J Med 2009, 360:1320-8.

\section{Changes Clinical Practice}

FI000 Factor 13

Evaluated by Karl-Dietrich Sievert 17 Apr 2009, Andreas Skolarikos 0 I May 2009, Corne Biesheuvel 07 May 2009, William Dale 24 Feb 2010

6. Etzioni R, Penson DF, Legler JM, di Tommaso D, Boer R, Gann PH, Feuer E): Overdiagnosis due to prostate-specific antigen screening: lessons from U.S. prostate cancer incidence trends. J Natl Cancer Inst 2002, 94:98I-90.

7. Draisma G, Etzioni R, Tsodikov A, Mariotto A, Wever E, Gulati R, Feuer $\mathrm{E}$, de Koning $\mathrm{H}$ : Lead time and overdiagnosis in prostatespecific antigen screening: importance of methods and context. J Natl Cancer Inst 2009, I 0 I:374-83.

8. Schröder FH: Screening for prostate cancer (PC)-an update on recent findings of the European Randomized Study of Screening for Prostate Cancer (ERSPC). Urol Oncol 2008, 26:533-4I.

9. Draisma G, Boer R, Otto SJ, van der Cruijsen IW, Damhuis RA, Schröder FH, de Koning HJ: Lead times and overdetection due to prostate-specific antigen screening: estimates from the European Randomized Study of Screening for Prostate Cancer. J Natl Cancer Inst 2003, 95:868-78.

10. Tsodikov A, Szabo A, Wegelin J: A population model of prostate cancer incidence. Stat Med 2006, 25:2846-66.

II. Steyn JH, Smith FW: Nuclear magnetic resonance imaging of the prostate. $\mathrm{Br} J$ Urol 1982, 54:726-8.

12. Kirkham AP, Emberton M, Allen C: How good is MRI at detecting and characterising cancer within the prostate? Eur Urol 2006, 50: 1163-74.

13. Engelbrecht MR, Jager GJ, Laheij RJ, Verbeek AL, van Lier HJ, Barentsz JO: Local staging of prostate cancer using magnetic resonance imaging: a meta-analysis. Eur Radiol 2002, 12:2294-302.

14. Wefer AE, Hricak H, Vigneron DB, Coakley FV, Lu Y, Wefer J, Mueller-Lisse U, Carroll PR, Kurhanewicz J: Sextant localization of prostate cancer: comparison of sextant biopsy, magnetic resonance imaging and magnetic resonance spectroscopic imaging with step section histology. J Urol 2000, 164:400-4.

15. Kitajima K, Kaji Y, Fukabori Y, Yoshida K, Suganuma N, Sugimura K: Prostate cancer detection with 3 T MRI: comparison of diffusion-weighted imaging and dynamic contrast-enhanced MRI in combination with T2-weighted imaging. J Magn Reson Imaging 2010, 31:625-31.

16. Turkbey B, Pinto PA, Mani H, Bernardo M, Pang Y, McKinney YL, Khurana K, Ravizzini GC, Albert PS, Merino MJ, Choyke PL: Prostate cancer: value of multiparametric MR imaging at $3 \mathrm{~T}$ for detection-histopathologic correlation. Radiology 2010 , 255:89-99.

17. Haider MA, van der Kwast TH, Tanguay J, Evans AJ, Hashmi AT, Lockwood G, Trachtenberg J: Combined T2-weighted and diffusion-weighted MRI for localization of prostate cancer. AJR Am J Roentgenol 2007, 189:323-8.
18. Jager G], Ruijter ET, van de Kaa CA, de la Rosette J], Oosterhof GO, Thornbury JR, Barentsz JO: Local staging of prostate cancer with endorectal MR imaging: correlation with histopathology. AJR Am J Roentgenol 1996, 166:845-52.

19. Mazaheri Y, Hricak H, Fine SW, Akin O, Shukla-Dave A, Ishill NM, Moskowitz CS, Grater JE, Reuter VE, Zakian KL, Touijer KA, Koutcher JA: Prostate tumor volume measurement with combined T2-weighted imaging and diffusion-weighted MR: correlation with pathologic tumor volume. Radiology 2009, 252:449-57.

20. Nakashima J, Tanimoto A, Imai $Y$, Mukai M, Horiguchi $Y$, Nakagawa $K$, Oya M, Ohigashi T, Marumo K, Murai M: Endorectal MRI for prediction of tumor site, tumor size, and local extension of prostate cancer. Urology 2004, 64:10I-5.

2I. Groenendaal G, Moman MR, Korporaal JG, van Diest PJ, van Vulpen M, Philippens ME, van der Heide UA: Validation of functional imaging with pathology for tumor delineation in the prostate. Radiother Oncol 2010, 94:145-50.

22. Bostwick DG, Grignon DJ, Hammond ME, Amin MB, Cohen M, Crawford D, Gospadarowicz M, Kaplan RS, Miller DS, Montironi R, Pajak TF, Pollack A, Srigley JR, Yarbro JW: Prognostic factors in prostate cancer. College of American Pathologists Consensus Statement 1999. Arch Pathol Lab Med 2000, I 24:995-I000.

23. Billis A, Guimaraes MS, Freitas LL, Meirelles L, Magna LA, Ferreira U: The impact of the 2005 international society of urological pathology consensus conference on standard Gleason grading of prostatic carcinoma in needle biopsies. J Urol 2008, 180:548-52.

24. Köksal IT, Ozcan F, Kadioglu TC, Esen T, Kiliçaslan I, Tunç M: Discrepancy between Gleason scores of biopsy and radical prostatectomy specimens. Eur Urol 2000, 37:670-4.

25. Giusti S, Caramella D, Fruzzetti E, Lazzereschi M, Tognetti A, Bartolozzi C: Peripheral zone prostate cancer. Pre-treatment evaluation with MR and 3D (I)H MR spectroscopic imaging: correlation with pathologic findings. Abdom Imaging 2010, 35:757-63.

26. Zakian KL, Sircar K, Hricak H, Chen HN, Shukla-Dave A, Eberhardt S, Muruganandham M, Ebora L, Kattan MW, Reuter VE, Scardino PT, Koutcher JA: Correlation of proton MR spectroscopic imaging with gleason score based on step-section pathologic analysis after radical prostatectomy. Radiology 2005, 234:804-14.

27. Crehange G, Parfait S, Liegard M, Maingon P, Ben Salem D, Cochet A, Funes de la Vega M, Cormier L, Bonnetain F, Mirjolet C, Brunotte F, Walker PM: Tumor Volume and Metabolism of Prostate Cancer Determined by Proton Magnetic Resonance Spectroscopic Imaging at 3T Without Endorectal Coil Reveal Potential Clinical Implications in the Context of Radiation Oncology. Int J Radiat Oncol Biol Phys 2010, [Epub ahead of print].

28. Joseph T, McKenna DA, Westphalen AC, Coakley FV, Zhao S, Lu Y, Hsu IC, Roach M 3rd, Kurhanewicz J: Pretreatment endorectal magnetic resonance imaging and magnetic resonance spectroscopic imaging features of prostate cancer as predictors of response to external beam radiotherapy. Int I Radiat Oncol Biol Phys 2009, 73:665-71.

29. Shukla-Dave A, Hricak H, Ishill N, Moskowitz CS, Drobnjak M, Reuter VE, Zakian KL, Scardino PT, Cordon-Cardo C: Prediction of prostate cancer recurrence using magnetic resonance imaging and molecular profiles. Clin Cancer Res 2009, I5:3842-9.

30. Onur R, Littrup PJ, Pontes JE, Bianco FJ Jr: Contemporary impact of transrectal ultrasound lesions for prostate cancer detection. J Urol 2004, I72:5। 2-4.

3I. Lughezzani G, Sun M, Budäus L, Thuret R, Shariat SF, Perrotte P, Karakiewicz PI: Effect of the number of biopsy cores on prostate cancer detection and staging. Future Oncol 2010, 6:38I-90.

32. Jiang J, Colli J, El-Galley R: A simple method for estimating the optimum number of prostate biopsy cores needed to maintain high cancer detection rates while minimizing unnecessary biopsy sampling. J Endourol 20I0, 24:I43-7. 
33. Scattoni V, Raber M, Abdollah F, Roscigno M, Dehò F, Angiolilli D, Maccagnano C, Gallina A, Capitanio U, Freschi M, Doglioni C, Rigatti P, Montorsi F: Biopsy schemes with the fewest cores for detecting $\mathbf{9 5 \%}$ of the prostate cancers detected by a 24 -core biopsy. Eur Urol 2010, 57:1-8.

34. Cirillo S, Petracchini M, Della Monica P, Gallo T, Tartaglia V, Vestita E, Ferrando U, Regge D: Value of endorectal MRI and MRS in patients with elevated prostate-specific antigen levels and previous negative biopsies to localize peripheral zone tumours. Clin Radiol 2008, 63:87I-9.

35. Amsellem-Ouazana D, Younes P, Conquy S, Peyromaure M, Flam T, Debré $B$, Zerbib M: Negative prostatic biopsies in patients with a high risk of prostate cancer. Is the combination of endorectal MRI and magnetic resonance spectroscopy imaging (MRSI) a useful tool? A preliminary study. Eur Urol 2005, 47:582-6.

36. Prando A, Kurhanewicz J, Borges AP, Oliveira EM Jr, Figueiredo E: Prostatic biopsy directed with endorectal MR spectroscopic imaging findings in patients with elevated prostate specific antigen levels and prior negative biopsy findings: early experience. Radiology 2005, 236:903-10.

37. Beyersdorff D, Taupitz M, Winkelmann B, Fischer T, Lenk S, Loening SA, Hamm B: Patients with a history of elevated prostate-specific antigen levels and negative transrectal USguided quadrant or sextant biopsy results: value of $M R$ imaging. Radiology 2002, 224:70I-6.

38. Susil RC, Ménard C, Krieger A, Coleman JA, Camphausen K, Choyke P, Fichtinger G, Whitcomb LL, Coleman CN, Atalar E: Transrectal prostate biopsy and fiducial marker placement in a standard I.5T magnetic resonance imaging scanner. J Urol 2006, I 75: I |3-20.

39. Hata $N$, Jinzaki $M$, Kacher $D$, Cormak R, Gering D, Nabavi A, Silverman SG, D'Amico AV, Kikinis R, Jolesz FA, Tempany CM: MR imaging-guided prostate biopsy with surgical navigation software: device validation and feasibility. Radiology 2001, 220:263-8.

40. Haker SJ, Mulkern RV, Roebuck JR, Barnes AS, Dimaio S, Hata N, Tempany CM: Magnetic resonance-guided prostate interventions. Top Magn Reson Imaging 2005, 16:355-68.

41. Beyersdorff D, Winkel A, Hamm B, Lenk S, Loening SA, Taupitz M: MR imaging-guided prostate biopsy with a closed MR unit at I.5 T: initial results. Radiology 2005, 234:576-8I.

42. Hambrock T, Somford DM, Hoeks C, Bouwense SA, Huisman H, Yakar D, van Oort IM, Witjes JA, Fütterer JJ, Barentsz JO: Magnetic resonance imaging guided prostate biopsy in men with repeat negative biopsies and increased prostate specific antigen. J Urol 2010, 183:520-7.

43. Mogami T, Harada J, Kishimoto K, Sumida S: Percutaneous MRguided cryoablation for malignancies, with a focus on renal cell carcinoma. Int J Clin Oncol 2007, I 2:79-84.

44. Pech M, Wieners G, Freund T, Dudeck O, Fischbach F, Ricke J, Seemann MD: MR-guided interstitial laser thermotherapy of colorectal liver metastases: efficiency, safety and patient survival. Eur J Med Res 2007, I 2: 16 I-8.

45. Schwarzmaier HJ, Eickmeyer F, von Tempelhoff W, Fiedler VU, Niehoff H, Ulrich SD, Yang Q, Ulrich F: MR-guided laser-induced interstitial thermotherapy of recurrent glioblastoma multiforme: preliminary results in 16 patients. Eur J Radiol 2006, 59:208-I5.

46. Mack MG, Straub R, Eichler K, Roggan A, Böttger M, Woitaschek D, Vog| TJ: MR-guided laser-induced thermotherapy in recurrent extrahepatic abdominal tumors. Eur Radiol 200I, I I:204 I-6.

47. Dick EA, Joarder R, De Jode MG, Wragg P, Vale JA, Gedroyc WM: Magnetic resonance imaging-guided laser thermal ablation of renal tumours. BJU Int 2002, 90:8I4-22.

48. Raz O, Haider MA, Davidson SR, Lindner U, Hlasny E, Weersink R, Gertner MR, Kucharcyzk W, McCluskey SA, Trachtenberg J: Realtime magnetic resonance imaging-guided focal laser therapy in patients with low-risk prostate cancer. Eur Urol 2010 , 58:173-7.

49. Ménard C, Susil RC, Choyke P, Gustafson GS, Kammerer W, Ning H, Miller RW, Ullman KL, Sears Crouse N, Smith S, Lessard E, Pouliot J, Wright V, McVeigh E, Coleman CN, Camphausen K: MRI-guided HDR prostate brachytherapy in standard I.5T scanner. Int J Radiat Oncol Biol Phys 2004, 59:|4|4-23.

50. Ares C, Popowski Y, Pampallona S, Nouet P, Dipasquale G, Bieri S, Ozsoy O, Rouzaud M, Khan H, Miralbell R: Hypofractionated boost with high-dose-rate brachytherapy and open magnetic resonance imaging-guided implants for locally aggressive prostate cancer: a sequential dose-escalation pilot study. Int J Radiat Oncol Biol Phys 2009, 75:656-63.

5I. Chen JC, Moriarty JA, Derbyshire JA, Peters RD, Trachtenberg J, Bell SD, Doyle J, Arrelano R, Wright GA, Henkelman RM, Hinks RS, Lok SY, Toi A, Kucharczyk W: Prostate cancer: MR imaging and thermometry during microwave thermal ablation-initial experience. Radiology 2000, 214:290-7.

52. Chopra R, Tang K, Burtnyk M, Boyes A, Sugar L, Appu S, Klotz L, Bronskill M: Analysis of the spatial and temporal accuracy of heating in the prostate gland using transurethral ultrasound therapy and active MR temperature feedback. Phys Med Biol 2009, 54:26I5-33.

53. Djavan B, Zlotta AR, Susani M, Heinz G, Shariat S, Silverman DE, Schulman CC, Marberger M: Transperineal radiofrequency interstitial tumor ablation of the prostate: correlation of magnetic resonance imaging with histopathologic examination. Urology 1997, 50:986-92.

54. Larson BT, Collins JM, Huidobro C, Corica A, Vallejo S, Bostwick DG: Gadolinium-enhanced $M R I$ in the evaluation of minimally invasive treatments of the prostate: correlation with histopathologic findings. Urology 2003, 62:900-4.

55. Song I, Kim CK, Park BK, Park W: Assessment of response to radiotherapy for prostate cancer: value of diffusion-weighted MRI at 3 T. AJR Am J Roentgenol 2010, I 94:W477-82.

56. Kim CK, Park BK, Park W, Kim SS: Prostate MR imaging at 3T using a phased-arrayed coil in predicting locally recurrent prostate cancer after radiation therapy: preliminary experience. Abdom Imaging 2010, 35:246-52.

57. Westphalen AC, Coakley FV, Roach M 3rd, McCulloch CE, Kurhanewicz J: Locally recurrent prostate cancer after external beam radiation therapy: diagnostic performance of I.5-T endorectal MR imaging and MR spectroscopic imaging for detection. Radiology 2010, 256:485-92.

58. Arumainayagam N, Kumaar S, Ahmed HU, Moore CM, Payne $\mathrm{H}$, Freeman A, Allen C, Kirkham A, Emberton M: Accuracy of multiparametric magnetic resonance imaging in detecting recurrent prostate cancer after radiotherapy. BJU Int 2010, 106:991-7.

59. Pisansky TM, Kozelsky TF, Myers RP, Hillman DW, Blute ML, Buskirk SJ, Cheville JC, Ferrigni RG, Schild SE: Radiotherapy for isolated serum prostate specific antigen elevation after prostatectomy for prostate cancer. J Urol 2000, 163:845-50.

60. Schild SE, Buskirk SJ, Wong WW, Halyard MY, Swanson SK, Novicki DE, Ferrigni RG: The use of radiotherapy for patients with isolated elevation of serum prostate specific antigen following radical prostatectomy. J Urol 1996, I56:I725-9.

6I. Leventis AK, Shariat SF, Slawin KM: Local recurrence after radical prostatectomy: correlation of US features with prostatic fossa biopsy findings. Radiology 2001, 219:432-9.

62. Casciani E, Polettini E, Carmenini E, Floriani I, Masselli G, Bertini L, Gualdi GF: Endorectal and dynamic contrast-enhanced MRI for detection of local recurrence after radical prostatectomy. AJR Am J Roentgenol 2008, 190: I 187-92.

63. Miralbell R, Vees H, Lozano J, Khan H, Mollà M, Hidalgo A, Linero D, Rouzaud M: Endorectal MRI assessment of local relapse after surgery for prostate cancer: A model to define treatment field guidelines for adjuvant radiotherapy in patients at high risk for local failure. Int J Radiat Oncol Biol Phys 2007, 67:356-6I. 
64. Cirillo S, Petracchini M, Scotti L, Gallo T, Macera A, Bona MC, Ortega C, Gabriele P, Regge D: Endorectal magnetic resonance imaging at I.5 Tesla to assess local recurrence following radical prostatectomy using T2-weighted and contrastenhanced imaging. Eur Radiol 2009, 19:76 I-9.

65. Sciarra A, Panebianco V, Salciccia S, Osimani M, Lisi D, Ciccariello M, Passariello R, Di Silverio F, Gentile V: Role of dynamic contrastenhanced magnetic resonance (MR) imaging and proton MR spectroscopic imaging in the detection of local recurrence after radical prostatectomy for prostate cancer. Eur Urol 2008, 54:589-600.

66. Choo R, Klotz L, Danjoux C, Morton GC, DeBoer G, Szumacher E, Fleshner N, Bunting P, Hruby G: Feasibility study: watchful waiting for localized low to intermediate grade prostate carcinoma with selective delayed intervention based on prostate specific antigen, histological and/or clinical progression. J Urol 2002, 167:1664-9.

67. van As NJ, de Souza NM, Riches SF, Morgan VA, Sohaib SA, Dearnaley DP, Parker CC: A study of diffusion-weighted magnetic resonance imaging in men with untreated localised prostate cancer on active surveillance. Eur Urol 2009, 56:98I-7.

FI000 Factor 6

Evaluated by Uri Lindner 08 Dec 2009

68. Fradet V, Kurhanewicz J, Cowan JE, Karl A, Coakley FV, Shinohara K, Carroll PR: Prostate cancer managed with active surveillance: role of anatomic MR imaging and MR spectroscopic imaging. Radiology 2010, 256: 176-83. 